\title{
Cornea Donor
}

National Cancer Institute

\section{Source}

National Cancer Institute. Cornea Donor. NCI Thesaurus. Code C153142.

Someone from whom a cornea is removed for transplantation or other purpose. 